\title{
ARTICLES ARTÍ́CULOS \\ JOURNALISTIC IDENTITY \\ AND AUDIENCE \\ PERCEPTIONS: Paradigm and models under construction in the African Great Lakes region
}

Copyright ( 2014 SBPjor / Associação Brasileira de Pesquisadores em Jornalismo

\author{
MARIE-SOLEIL FRÈRE \\ Université libre de Bruxelles
}

\begin{abstract}
This article is based on a research conducted in three African countries (Burundi, Rwanda and the Democratic Republic of the Congo), focusing on the recent evolution of the journalistic profession and the way journalists are perceived today and represented by members of the audience polled in five localities of the region. In the last twenty years, journalism has been deeply transformed, following the liberalization of the media sector, on one hand, and the murderous civil wars which marked the three countries on the other hand. New formats and new roles have appeared for the media, as well as new professional standards for journalists (codes of ethics, regulations from regulatory authorities, journalists education and training curricula, professional associations), often encouraged by foreign donors and international NCOs. This paper aims at showing that, behind these changes, a new « journalistic paradigm » has taken shape, a consequence of both internal dynamics within the profession and external assignments (imposed by the State and the evolution of the market), and also of new demands emanating from the public. In an unstable political, economic and security context, the changes of the journalistic paradigm have transfigured media content, as well as the perception by the local public of the role that journalists have to play in society, and of what the citizens may expect from them, in a region where democracy is still widely under construction.
\end{abstract}

Keywords: Journalistic paradigm. Rwanda. Burundi. Democratic Republic of the Congo. Journalistic identity.

\section{IDENTIDADE JORNALÍSTICA E PERCEPÇÕES DO PÚBLICO: paradigmas e modelos em construção na região dos Grandes Lagos (África)}

RESUMO - Esse artigo se baseia em uma pesquisa conduzida em três países africanos (Burundi, Ruanda e República Democrática do Congo), sobre a evolução recente da profissão de jornalista e sobre a maneira como ela é, hoje, percebida e representada por ouvintes, entrevistados em cinco localidades da região. Após duas décadas, o jornalismo se transformou, por um lado, com a liberalização do setor de mídias e, por outro, com as guerras civis sangrentas que marcaram os três países. Os novos formatos e os novos papéis reinvindicados pelas mídias apareceram, assim como os novos referenciais profissionais (códigos deontológicos, instâncias de autorregulação, cursos de formação, associações profissionais), por vezes incentivados por doadores de fundos e ONGs internacionais. $\mathrm{O}$ artigo mostra que, por trás dessas mudanças, é um novo paradigma jornalístico que realmente foi elaborado, fruto de dinâmicas internas da profissão e de assignações externas (pelo Estado e a evolução do mercado), mas também das novas exigências do público. Em um contexto político, econômico e de segurança problemático, as mutações do jornalismo têm transformado o discurso midiático, mas igualmente transformado a percepção que o público tem do lugar do jornalismo na sociedade, e de que os cidadãos estão suscetíveis a esperar dele, em uma região na qual grande parte da democracia ainda está em construção. Palavras-chave: Paradigma jornalístico. Ruanda. Burundi. República Democrática do Congo. Identidade Jornalística. 


\section{IDENTIDAD PERIODÍSTICA Y PERCEPCIÓN DE LA AUDIENCIA: paradigma y modelos en construcción en la región de los Grandes lagos en África}

RESUMEN - El presente artículo está basado en una investigación llevada a cabo en tres países africanos (Burundi, Ruanda y la República democrática del Congo). A partir de encuestas realizadas en cinco localidades de la región, estudiamos la manera en que los periodistas son percibidos por la audiencia. En los últimos veinte años, el periodismo se ha visto profundamente transformado a raíz de la liberalización del sector de los medios, por un lado, y de las guerras civiles que han tenido lugar en los tres países, por el otro. Nuevos formatos y nuevos roles han aparecido en los medios, así como nuevas normas profesionales (códigos de ética, regulaciones provenientes de organismos reguladores, capacitación para periodistas, asociaciones profesionales), a menudo fomentadas por donantes extranjeros y ONG internacionales. Este artículo pretende mostrar que, detrás de estos cambios, un nuevo "paradigma periodístico" está emergiendo, como consecuencia a la vez de dinámicas internas a la profesión y de obligaciones externas (impuestas por el Estado y por la evolución del mercado), así como de nuevas exigencias provenientes del público. En un contexto político y económico inestable, el nuevo paradigma periodístico ha modificado tanto los contenidos mediáticos como la percepción por parte del público local del papel que los periodistas deben jugar en la sociedad, en una región en la que la democracia está aún construyéndose.

Palabras clave: Paradigma periodístico. Ruanda. Burundi. República Democrática del Congo. Identidad periodística.

Over the past 20 years, the Democratic Republic of Congo (DRC), Burundi and Rwanda have not only witnessed the liberalization of the media sector (with the emergence of private media in the early 1990s) but also been the scene of an armed conflict that resulted in the death of hundreds of thousands if not millions of people. These two historical developments have left profound marks on the journalism sector in the three countries and on the referents with which the sector identifies. This paper rests on field work conducted over the past decade in the African Great Lakes region' and aims to draw attention to the shift in identity that has occurred within the profession over the past two decades under the impact of internal and external forces. Indeed, if we refer to the approach of Charron and De Bonville, we can consider that a real change of "journalistic paradigm" actually occurred in these three countries. Referring to a journalistic practice situated in time and space, the notion of "paradigm" leads us to consider the community of the media professionals as a group "sharing the same definition of the reality and having common techniques to describe it." The notion refers at the same time to a specific normative system (which can be developed outside of the profession or emerge from practice) and to exemplary models and values recognized and shared by the members of the community, integrated through (among other things) raining curricula. The notion of "journalistic paradigm" differs from 
the concept of "professional habitus" developed by Pierre Bourdieu (1980), because it does not focus on the tendencies ("dispositions") interiorized by an individual but on a socio-cultural structure "that the journalist appropriates gradually and whose elements can be possibly incorporated into his/her individual habitus if the duration and the intensity of the professional practice is sufficient." The notion of "journalistic paradigm" makes it possible to scrutinize the major evolutions which have marked the media and their practitioners in Congo, in Burundi and in Rwanda for the past two decades and to analyze these transformations as a real change of configuration (in Norbert Elias's sense, 1991.)

The first part of the text is dedicated to a historical reminder which highlights how, in the previous configuration or paradigm, the public authority framed and oriented the role of journalists, from the time of independence up till the beginning of the 1990s. The second part deals with the internal and external processes in the media sector which have recently entirely transformed the media content, the professional practices and the environment in which journalism is practiced. In this new configuration, journalism remains a regulated practice, but the norms do not emanate mainly from the political authority anymore: instructions and recommendations are now elaborated by the profession itself, as well as by other actors, such as the international donors that support the media financially. Finally, the third part of the paper analyses the data collected in a study of the audiences of radio stations in five cities of these three countries: the data give an insight as to what extent the perceptions of what a citizen is entitled to expect from a professional journalist has also changed profoundly following the liberalization of the sector and the development, then reduction, of the armed conflicts. The reconfigurations of the environment (due to the opening to political and media pluralism, and to technological change) has led to a true change of paradigm, which is illustrated in the way the public now understands the role of journalists in society; a main factor in the construction of the professional identity of the journalists.

\section{A SWITCH OF PARADIGM}

Ever since it has attempted to define itself, the profession of journalist has always been organized by both external forces, in particular the public authorities but also the media's audience, 
and by internal forces seeking to formulate, guarantee and convey the principles intended to guide the exercise of the profession. In the African Great Lakes region, an area which has been through considerable upheavals in both the political field and the media sector during the past twenty years, norms, values and professional routines around which the journalistic practice is implemented have been subject to deep change, as will be described in the first section of this paper.

\subsection{Thirty years of "development journalism"}

During the 30 years that followed the declarations of independence in 1960 (for the DRC) and in 1962 (for Burundi and Rwanda), the journalists of these three countries were subjected to an essentially external, authoritarian and unilateral (non-consultative) definition of the nature and missions of their profession, the media existing under a state monopoly, whether de jure or de facto. ${ }^{2}$ With the exception of a small number of Catholic media with a denominational vocation, and a number of cultural or sports media, all news outlets were tied to the State or to the country's single party. Journalists were zealous civil servants, regime propagandists in charge of praising government activity, and often devoted to the cult of personality of the President of the Republic. ${ }^{3}$ The missions devolved upon journalists were relatively clear in official documents and discourses. For example, article 6 of the 1976 press law in Burundi ${ }^{4}$ stipulated that "Burundian journalists must always behave as patriots committed to, and aware of the party's ideals, the only authority responsible for the country's wellbeing." It fell to Burundian journalists to contribute to "the education and civic training of Burundians and the mobilization of the masses to implement government plans that must remain the primary concern of media owners and journalists." 5

In the Congo (renamed Zaire in 1971), the press was governed by a law of $1970^{6}$, revised in 1981. According to the Ministry of Information at the time, "The Zairean understanding of news rests on the people's aspirations for development and on the guidelines of the general policy developed by the public authorities. News services are organized like public utility services to provide State information." In such a context, Sakombi Inongo, Information Commissioner during the Mobutu regime, formulated the journalist's missions as follows: "The Zairean journalist is an officer committed to the realization of 
the MPR's vision of society"." It is his "sacred duty to unmask and denounce all conspiracies against our country's territorial integrity, against national security, against public order, against the lives of the Citizens who govern the country, against Mobutism, i.e., the ideology, doctrine, political philosophy, action and values that have transformed our country and rehabilitated its people ${ }^{9}$."

Zairean journalists had no room for manoeuvre. Article 41 of the order-law of 1981 organizing the statutes for journalists working in Zaire stipulated that "The agent must personally carry out all obligations that befall him by virtue of his functions. He will personally be held accountable to his superiors for the execution of the orders he has received."

For its part, the Rwandan press was without a reference legal framework, but in a speech dating from October 12 1968, President Grégoire Kayibanda clearly articulated the preferred orientation of the media: "informing the masses about the national programme is a necessity. The written press, radio stations, cinemas, photographs, gatherings and popular rallies that only insist on the negative aspect of life instead of showing the objective and pointing out even the modest means to achieve it will be guilty of sabotaging the Nation's development. All those in the country who have at their disposal this type of means of communication (and of information and training) are responsible for the people's stagnation or progress ${ }^{10}$." Later, his successor, President Juvénal Habyarimana, would go one better: "the news will serve as a link between the rulers and the citizens. This is to say that the rulers also need to be enlightened and criticized positively. But this criticism must not be synonymous in our country with deliberate disrespect and offence (...) That is why, in our country, my government is seeking to develop, insofar as its means allow it to do so, healthy news, meeting the objectives and spirit of our plan for action, lauding, without chauvinism, but proudly, the soul of our people..." ${ }^{11 "}$

Activists for the single party, defenders of the nation and soldiers of development, journalists were first and foremost a mouthpiece for government propaganda.

And in fact journalists were specifically trained for this purpose. From its creation in 1973, the Institute for Information Sciences and Technologies (ISTI) in Kinshasa formed generations of Congolese but also Burundian and Rwandan journalists. ${ }^{12}$ Founded on the initiative of the Department of National Orientation, the ISTI 
aimed to avoid the "rupture" brought about by the training in European schools. As its former director explained, "the training given in European or American schools to future journalists from developing countries takes place in a socio-political context different from the one in which these agents will one day have to work. And yet it is essential that they be trained in close collaboration with the global cultural, political and economic environment which they will one day have to report on." A journalist trained at ISTI will therefore be "at the service of national development of which he really is the tool. (...) It is in the context of the party that he in fact enjoys the freedom of expression in his dual capacity as an activist and a citizen. His freedom to exercise his profession is both conceived and practiced in the context of the national party ${ }^{13}$."

Thus, during 30 years, the law, the official vulgate and the training courses combined to confine the journalist to the role of spokesperson for the rulers.

\subsection{The 1990s: emancipated journalists, fighting journalists}

In the early 1990s, the journalists of Zaire, Burundi and Rwanda threw off this yoke in the wake of the wave of liberalization known as the "African spring." Simultaneously to the development of the multi-party system, the authorization of new private media (first in the written press, then in the audiovisual media) led to a profound change in the media's role, but also in the way journalists perceived themselves, envisaged their mission and organized themselves to exercise it. The new private media immediately prided themselves on their new roles: acting as an opposition force, contributing to the democratic debate, acting as the "watch dogs" of democracy, combating impunity, acting as a mouthpiece for civil society, being the "voice of the voiceless," providing local news, and so forth. The emergence of this new position would lead a long-time observer of the African media scene, the journalist Thierry Perret, to talk of "the invention of journalism in French-speaking Africa ${ }^{14}$."

The sector's liberalization, ratified by the enactment of new press laws ${ }^{15}$, resulted in an important mutation of the role claimed by journalists, encouraged by a change in the sociological profile of the media professionals. Indeed, the new private media hired a lot of young people lacking a degree in the field and driven above all by the desire to express themselves freely and to denounce injustices. 
They contributed to the renewal of the profession, which took shape through the development of new perspectives and new formats: newspapers specializing in analysis and commentary with critical editorials, participative programs open to the public's views and questions, pluralistic debates presenting a range of opinions, inquiries and investigations into bad governance or human rights violations...

The profession's transformation was therefore twofold, combining both the new formats and the sociological evolution of the journalists. The editorials of the press of the day are quite telling in this respect. In Burundi, private newspapers like Le Citoyen, La Semaine or Panafrika offered fresh perspectives. For Le Citoyen, its mission was to "inform its readers, without fear of telling the truth, even when it hurts ${ }^{16}$." La Semaine positioned itself as a "champion of independence ${ }^{17}$ ", "different from the public press ${ }^{18}$." In Zaire, where more than 120 newspapers saw the day in a year (1990-1991)19, most of them short-lived, they were seen to "confront constantly, with an extreme virulence, all the organs of government, including the president ${ }^{20}$." Besides criticizing the authorities, the newspapers see themselves as "teaching democracy." Thus Le Potentiel claimed it was necessary that "those who know something about democracy stimulate reflection, inform and prepare the population with regard to democratic procedures and presuppositions ${ }^{21}$."

But the period that saw the birth of new private papers (a dozen in Burundi and Rwanda, several hundreds in the huge Zaire) also saw the birth of highly politicized papers with a radical tone, the spearheads of political parties that were sometimes inclined to play the ethnic card to gain or remain in power. In Zaire, the press was "a single-opinion press, i.e., committed newspapers at the service of political groups ${ }^{22}$." Papers such as L'Aube de la Démocratie, L'Indépendant and Le Carrefour des Idées in Burundi, or the notorious Kangura or Radio Télévision libre des Mille Collines (RTLM) in Rwanda became textbook examples of what is called "hate media23." In 1993 the head of the Rwandan Office for Information deplored: "What have our journalists become? (...) In recent years Rwandan journalists have turned into militants for one or other cause. The state press and the private press have outdone one another in inciting violence and racial hatred. Information has made way for prejudice and propaganda. Journalists have become political agitators...24"

This politically committed, even extremist fringe of the media, driven by militant-journalists, would, if not contribute to the 
outbreak of war (Burundi plunged into a civil war in 1993, Rwanda was the scene of a genocide in 1994), at least serve as platforms for the destructive propaganda of the power-hungry belligerents. In Zaire, which became the DRC in 1997, the start of the first war (1996-1997), and later of the second war (1997-2003), would also transform certain media (including the public broadcaster RTNC Radio Télévision Nationale Congolaise) into propaganda machines.

When peace was restored, either after one of the belligerents seized power (in Rwanda in 1994) or in the wake of a peace agreement (in Burundi in 2000, in the DRC in 2003), where the media had sometimes contributed to stirring up hostilities, the reconstruction process, supported massively by the international community, did not neglect the media. The latter emerged weakened and discredited by the political crises, at the same time that they were called on to play an essential role in reinstating democratic regimes, in particular at the moment of the elections organized to put a definitive end to the rifts due to civil war ${ }^{25}$. This is why the peace processes and their foreign backers often paid close attention to this sensitive sector and ambitious programmes were financed seeking to promote "peace journalism ${ }^{26}$," to support the creation of media and contents that were "sensitive to conflicts 27 ", to encourage the education sector and professional associations.

\subsection{The dynamics of reform: the age of self-identification}

In order to break with the militant journalism of the conflict period, the external interventions of donors and international NGOs suggested or encouraged, in the three countries, the construction and formalization of new professional referents by and for journalists. As a result, codes of professional ethics were adopted in the three countries almost concurrently: in 1997 (revised in 2003) in Burundi28, in 2004 in the DRC, and in 2005 in Rwanda ${ }^{29}$. Simultaneously, and still relying on the benevolence of the financial backers and donors, eager for "post-conflict" reconstruction, the journalists established self-regulatory authorities: OPB (Burundi Press Council), OMEC (Congo Media Council), and RMEC (Rwanda Media Ethics Commission) ${ }^{30}$.

The new codes of journalistic ethics reveal a very different profession, one which contrasted with the discourses and legal frameworks in effect during the preceding decades, but also with more recent practices that emerged before and during the wars. 
They reveal the stigmata of the preceding decade and reflect the dual dynamic of liberalization and conflictuality that transformed the profession of journalist.

A close reading of these codes uncovers, firstly, a clear desire to rein scribe the profession in international reference frameworks (a far cry from the "authentic" journalism practiced during the era of state monopoly or "patriotic" journalism during the conflict era). The Congolese and Rwandan codes refer explicitly to the Munich Declaration (DRC) or the Universal Declaration of Human Rights (Rwanda). The Burundian code of ethics refers to "universal values": "peace, tolerance, democracy, human rights..." (art. 1). These notions also feature explicitly in the Congolese code, which inscribes the journalist's work in the context of "the universal values of humanism: peace, equality, human rights, social progress" (art. 12).

Secondly, the conflict-ridden past has left a clear mark on these codes and is visible in explicit references to history and to a certain number of violations, but also in the insistence on the notion of the journalist's "responsibility." The preface to the Rwandan code alludes directly to the past: "learning the lesson of a pitiful press, shamefully partisan and inciting hatred which culminated in the 1994 genocide, the media community resolves to adopt, promote and conform to principles designed to construct a strong, independent, dynamic and responsible press." The three codes clearly mention their "refusal to incite hatred" (art. 2 Burundi); recommend journalists to "cease inciting any form of violence, including hatred, tension and animosity based on ethnicity or religion" (art. 13 Rwanda); or to "ban (...) incitements to hatred (religious, ethnic, tribal, regional or racial) as well as the apology of any negative value" (art. 5 DRC).

The codes return regularly to the journalist's responsibility towards the audience (and no longer towards the authorities or any hierarchy). In Rwanda, "journalists, publishers and newspaper owners always have to keep in mind their responsibilities towards the public, being at the service of the truth inherent to our culture, defending and preserving the respect and prestige of the press while remaining responsible towards their peers and the listeners/spectators/readers by doing their best and with the greatest conviction." The preface to the Congolese code insists on the fact that journalists are "aware that the responsibility of journalists towards the public prevails over any other responsibility, in particular with regard to their employers and the public authorities." 
Lastly, distinguishing themselves from journalism at the service of development or national unity, the journalists now claim to be driven by the search for truth: "the guiding principle for all journalists is to serve the right of citizens to know the truth," claims the Rwandan code (art. 1). Journalists must "abhor untruths and have the search for truth as their ultimate objective" (art. 3 Burundi); they must "seek at all times to make the truth prevail, through the precise, honest, accurate and loyal coverage of duly established and verified facts and information obtained without blackmail and without deceiving the good faith of anyone" (art. 6 DRC).

The codes also mention a series of rights that the journalists must be able to claim: access to sources, conscience clause, material and moral security (contract), protection and security.

The redefinition of the profession, at work through selfregulatory dynamics, also led to the establishment of new training courses and education curricula. In Rwanda, where there had never been a training institute for journalism, the School of Journalism and Communication was established in 1996 in the wake of the genocide, at the National University of Rwanda (with the initial support of Unesco). In 2008 there followed the Great Lakes Media Centre (GLMC), a training center for professionals already working ${ }^{31}$. In Burundi ${ }^{32}$, after the opening of two bachelor's programmes in communication in private universities in the early 2000s, the University of Burundi launched, in 2008, with the support of Belgian university development aid, a Masters programme specializing in journalism. Moreover, besides a Press House founded in 1997 (whose mission was notably to provide professional journalists with retraining opportunities), and a Studio- School developed by the Burundian Association of Radio Broadcasters (ABR), in 2009 the media professionals created the CFM (Media Training Centre for Professionals) with the support of the European Union. Initiatives also flourished in the DRC, to support either existing university programmes in charge of initial training (Ifasic, FCK, Unikin, etc.) ${ }^{33}$ or ongoing training centers like the ICA (Congolese Audiovisual Institute). The training of journalists was also seen as a promising market by the many private highereducation establishments that emerged in the wake of the sector's liberalization. The range of courses on offer in these institutions left a lot of room for professional ethics and the teaching of new principles (ethical, ${ }^{34}$ but also legal and regulatory) that would henceforth guide the profession. 
Journalistic training has been an ongoing concern over the past decade for the public authorities, the donors and the journalists themselves. But the desire to have journalism practiced by people trained in accordance with "universal principles," and this in order to avoid any violations, has been pushed very far by the public authorities, and too far according to the profession... Indeed, in 2009, during the revision of the Rwandan press law, a condition was added to the exercise of the profession of journalist. Article 2 of the new law defined the journalist - in addition to the traditional features that characterize his daily activities - as "any person who has completed studies related to journalism or communication and who has a bachelor's degree from a university or a bachelor's degree from a journalism and communication institute or from another recognized center delivering a similar degree...35" This imposed condition generated much debate within the profession, and eventually this requirement was taken out in the last press law enacted in 2013. But a similar debate took place once more in Burundi, where the new law adopted in June 2013, also provides that journalists, to be recognized as such, must "hold at least a bachelor's degree in journalism or the equivalent or any other degree of at least the level of a master's degree combined with a certified training internship or at least two years of experience in a newspaper...36".

These new measures are a source of concern for many professionals who have been working for many years without the required degree and will thus be compelled to go back to school... or to soon face trouble. This renewed involvement of the public authorities in the definition of the profession, by imposing legal conditions, exposes a blatant desire of the ruling classes to better control the information circulating in the public space. Following a period where free rein was given to journalists to redefine and selfregulate the profession internally, external interventions are surfacing once more in the configuration of professional identities.

\section{FROM DISCOURSE TO PRACTICE}

One of the reasons behind the public authorities' renewed involvement in the definition of the profession's identity is that the self-organization efforts, largely encouraged by the international partners, faced contexts particularly unsuited to the implementation of the profession's habitual models. Independence, impartiality, 
cross-checking, verification and completeness of information are journalistic ideals that are difficult to follow in a problematical economic environment, in the face of political actors liable to exert substantial pressure on journalists and media owners who are reluctant to pay wages. ${ }^{37}$

The situation is all the more difficult for journalists since, despite peace processes and two cycles of "free and democratic"38 elections, the political situation of these three countries is still uncertain, with war still ongoing in part of the country (DRC), permanent security threats (Burundi) or a regime that has curtailed freedoms (Rwanda).

The implementation of several new principles of the profession, as defined by the journalists themselves, faces practical difficulties of an economic, statutory and editorial order.

As regards economic constraints, the overwhelming majority of Burundian, Rwandan and Congolese media struggle to survive, forcing journalists to work in often precarious wage conditions. A journalist in the DRC earns between $\$ 30$ and $\$ 120$ per month (except for journalists working in one or other rare media enjoying consistent international support, like Radio Okapi, a station funded for the past decade by Monusco ${ }^{39}$ ). In Burundi, the average wage reaches $\$ 120$, even if journalists with important responsibilities can earn up to $\$ 300$ or $\$ 500$ per month. In Rwanda, wages also waver between $\$ 100$ and $\$ 200$. Moreover, wages are often delayed because, as soon as the company faces any budget instability, the staff's wages are sacrificed in order to reimburse the creditors.

In these post-conflict countries, where the standard of living is still weak, the purchase of a newspaper or television set in particular remains a privilege. While listening to the radio is financially more accessible, the perspective of an impoverished audience is of no great appeal to potential advertisers, and so the audiovisual media are struggling to develop their advertising revenue. As a result, a number of practices have developed to enable journalists to accomplish the job of collecting and processing information, which we can globally call "paid coverage of events" or, as the Burundian journalists say, "prise en charge totale." ("total care taken") This practice involves journalists accepting compensation from the organizers of events in exchange of an article or programme reflecting the client's concerns. If this practice is widespread in Burundi in its most institutionalized form, i.e., programmes or articles "sponsored" by institutions, it is 
known in the DRC and in Rwanda in a more individualized form, each journalist personally negotiating his services. It is called "coupage" ("cutting") or "transport" in the DRC, "giti" ("tree") in Rwanda, or "per diem" in Burundi.

This type of practice is firmly condemned by the codes of ethics of the three countries. Article 7 of the Congolese code enjoins professional journalists to "refuse any gift from sources of information, to refuse any advantage or present in exchange for concealing information, any gratification in exchange for the publication, distortion or suppression of information." In Rwanda, article 25 recommends that journalists "refrain from accepting bribes or favours in any form or any obligation liable to compromise or harm the integrity of the profession." In Burundi, article 10 provides that "journalists will accept no gift whereby their skills, influences or relations would be liable to be exploited. Journalists must not behave like press officers."

The practice of paid coverage developed in a context of statutory fragility for journalists, in countries where there are no collective agreements protecting them and where they often work without a contract, sometimes even without wages. However, journalists have provided clear measures in their codes on these matters. Article 20 of the Congolese code stipulates that "the journalist is not only entitled to benefit from collective agreements but is also entitled to a personal contract, ensuring the material and moral security of his work as well as a salary corresponding to his social role and sufficient to guarantee his economic independence." Article 21 of the Burundian code provides that: "In view of his role and responsibilities, the journalist is entitled to a contract that ensures his material and moral security as well as a salary that guarantees his economic independence."

Despite repeated demands from professionals, no legislation has reinforced the status of journalists. In addition, the absence of any economic independence often translates into an absence of editorial independence.

Editorial difficulties also originate in another contextual characteristic which impedes the exercise of the profession: the absence of any guarantee of access to public information. In a situation where the public authorities are in no rush to "account" for their actions, journalists struggle to implement the "right of the public to information," one of the foundations of their proclaimed professional 
identity, included by journalists in their reference documents. Article 17 of the Congolese code claims for journalists "free access to all sources of information and the right to investigate freely all facts that influence public life". Article 17 of the Burundian code also states that "the journalist, in the exercise of his profession, has access to all sources of information. He has the right to investigate freely all facts that concern public life". Article 33 of the Rwandan code states that he must "ensure the protection and preservation of the freedom of the press, the right to free speech and expression, and free access to information". But in these countries governed by former members of armed rebel movements, a tradition of transparency and information sharing is struggling to take root.

The constraints of the environment thus impede the implementation of the profession's principles adopted by the journalists themselves. The ensuing violations often provide the public authorities with an excuse to justify their regulatory or moderating intervention. But the authorities' room for manoeuvre to contain journalists in a more rigid framework and to keep them closer to their own concerns is often limited by another group of actors that also believes it is entitled to outline its definition of the profession of journalist: the media's public. Indeed, liberalization not only meant a new focus on the references generated internally, but it also led to the emergence of new claims and new demands from the public as to what is currently expected from professional journalists. This will be the focus of our last section

\section{IN THE EYES OF THE PUBLIC: RENEWED CONFIDENCE, NEW DEMANDS}

Over the past ten years, the development of the journalism sector not only changed the profession's discourse about itself, but also transformed the perception the public has of the journalist's role in society and what citizens are entitled to expect from him.

To illustrate this change, we are going to study the results of a survey conducted between 2010 and 2012 and involving about 1,300 listeners in five cities of the region (Bujumbura, Kigali, Butare, Bukavu and Goma) ${ }^{40}$. Carried out in collaboration with local listenerssurveyors, the survey aimed to outline the general position of the radio in people's everyday lives. Thanks to a few questions focused on the profession of journalist, the survey revealed the popularity 
of certain professionals in the region and the reasons evoked by the respondents to justify the particular esteem in which they held these star presenters. The answers collected by the surveyors bring to light the characteristic features of the "model" journalist in the mind of the different categories of listeners, ${ }^{41}$ the parameters that today define the "good" journalist for listeners in the region (radio being the leading media providing access to information). ${ }^{42}$ The new models currently appreciated by the public make it possible to measure the extent to which the image of the profession has changed. The following table identifies the journalists most cited as favourite by the respondents, the specific show that they are presenting and the station in which they work.

Table 1 Favourite journalists cited

\begin{tabular}{|c|c|c|c|c|c|c|c|c|c|}
\hline \multicolumn{2}{|c|}{\begin{tabular}{|c|} 
Burundi \\
Bujumbura (306 \\
respondents)
\end{tabular}} & \multicolumn{2}{|l|}{$\begin{array}{c}\text { DRCONGO } \\
\text { Bukavu (286) }\end{array}$} & \multicolumn{2}{|c|}{$\begin{array}{l}\text { DRCONGO } \\
\text { Goma (225) }\end{array}$} & \multicolumn{2}{|c|}{$\begin{array}{c}\text { RWANDA } \\
\text { Butare (226) }\end{array}$} & \multicolumn{2}{|c|}{$\begin{array}{c}\text { RWANDA } \\
\text { Kigali (467) }\end{array}$} \\
\hline $\begin{array}{l}\text { Domitille } \\
\text { Kiramvu } \\
\text { Journal parlé } \\
\text { kirundi (radio } \\
\text { news in Kirundi } \\
\text { RPA }\end{array}$ & $62 \%$ & $\begin{array}{l}\text { Jolly Kamuntu } \\
\text { Paix et } \\
\text { développement* } \\
\text { (Peace and } \\
\text { development) } \\
\text { Radio Maendeleo }\end{array}$ & $6 \%$ & \begin{tabular}{|l|} 
Magloire Paluku \\
Faucon Faucon \\
*Journal Parlé \\
(Radio news) \\
Club de Réflexion \\
(Reflection Club) \\
Kivu One
\end{tabular} & $48 \%$ & $\begin{array}{l}\text { Ali Youssouf } \\
\text { Mugenzi } \\
\text { Imvo } \\
\text { n'imvano * } \\
\text { (Revelation) } \\
\text { BBC }\end{array}$ & $23 \%$ & $\begin{array}{l}\text { Ali } \\
\text { Youssouf } \\
\text { Mugenzi } \\
\text { Imvo } \\
\text { n'imvano * } \\
\text { (Revelation) } \\
\text { BBC }\end{array}$ & $19 \%$ \\
\hline $\begin{array}{l}\text { Serge Nibizi } \\
\text { Kabizi* (The one } \\
\text { Who knows) } \\
\text { RPA }\end{array}$ & $35 \%$ & $\begin{array}{l}\text { Jean-Baptiste Baderha } \\
\text { Paix et développement } \\
\text { (Peace and } \\
\text { development)/Pleins } \\
\text { feux* (Spotlight) } \\
\text { Radio Maendeleo / } \\
\text { Canal Futur }\end{array}$ & $5 \%$ & $\begin{array}{l}\text { Hubert Furuguta } \\
\text { Faucon Faucon * } \\
\text { (Hawk Hawk) } \\
\text { Journal parlê } \\
\text { (News) } \\
\text { Radio Colombe } \\
\text { / Kivu One }\end{array}$ & $10 \%$ & \begin{tabular}{|l|} 
Emma \\
Claudine \\
Imenye nawe* \\
(Know \\
yoorself) \\
Radio Salus
\end{tabular} & $16 \%$ & $\begin{array}{l}\text { Ali Suddy } \\
\text { Show Biz, } \\
\text { Sunday } \\
\text { Night } \\
\text { Isango Star }\end{array}$ & $6 \%$ \\
\hline $\begin{array}{l}\text { Gilbert } \\
\text { Niyonkuru } \\
\text { Nomukura Hé* } \\
\text { (Where is my } \\
\text { beloved one?) } \\
\text { RPA }\end{array}$ & $5 \%$ & $\begin{array}{l}\text { Pacifique } \\
\text { Zikomangane } \\
\text { Journal des Radios } \\
\text { Clubs* (News from } \\
\text { Radio Clubs) Radio } \\
\text { Maendeleo }\end{array}$ & $5 \%$ & $\begin{array}{l}\text { Juan Gomez } \\
\text { Appel sur } \\
\text { l'actualité * } \\
\text { (Call in on } \\
\text { current events) } \\
\text { RFI }\end{array}$ & $12 \%$ & $\begin{array}{l}\text { Tidjara } \\
\text { Kabendera } \\
\text { Thèätre/ } \\
\text { musique } \\
\text { (Theatre and } \\
\text { music) Radio } \\
\text { Rwanda }\end{array}$ & $6 \%$ & $\begin{array}{l}\text { Tidjara } \\
\text { Kabendera } \\
\text { Thèätre / } \\
\text { Musique } \\
\text { Radio } \\
\text { Rwanda }\end{array}$ & $5 \%$ \\
\hline
\end{tabular}

Who are the star radio presenters in the Great Lakes region and what does their profile reveal in terms of large parts of the population's expectations towards journalists?

Three figures stand out who were mentioned by more than a third of listeners. In Bujumbura, Domitille Kiramvu, a presenter of the midday radio news in Kirundi on a local private station (RPA: Radio Publique Africaine), is cited as "favourite journalist" by $62 \%$ of the 306 people surveyed. Employed by a media positioning itself as "the voice of the voiceless", Kiramvu symbolizes critical freedom, but also field work and the attention paid to the everyday problems 
of Burundians. The respondents insisted on her courage, daring and proximity to the population.

Serge Nibizi, chosen by one in three listeners in Bujumbura, is another journalist working with the same station. He hosts a very popular morning programme ("Kabizi") 43 , in which he receives a guest who responds live to questions from the audience and himself. The programme's participatory character, Nibizi's capacity to "ask the right questions" and "to give people the opportunity to speak out" are the reasons for his success. In Goma (DRC), Magloire Paluku is the directorfounder of the local radio Kivu One: his immense popularity (almost one in two people chose him as a "favourite journalist") rests on the programme he presents ("Faucon Faucon"), a satirical programme that is unafraid to denounce the dysfunctions of the local administration. While the journalists mentioned in Burundi and the DRC all work in local media, in Rwanda, the most frequently mentioned journalist, Ali Yusuf Mugenzi, hosts programmes in Kinyarwanda in a radio that broadcasts from outside the country: a Rwandan journalist working at the BBC in London, he presents in particular a weekly programme that is broadcast every Saturday at 8 a.m. Entitled "Imvo n'Imvano," it focuses on news in the Great Lakes region and is very popular in Rwanda where, according to respondents, it allows them to "hear contradictory perspectives" and "brings together people who do not always agree," in a context where local radios have adopted a very consensual tone. Ali Yusuf Mugenzi is mentioned as the journalist of reference by one in four listeners in Butare and one in five in Kigali44.

When we look at the qualities for which these journalists are particularly appreciated by the respondents, we notice that they are similar in the different localities: these journalists are "courageous," "dare speak up," "are not afraid of the government," "tell the truth," "ask the right questions," "let people with different opinions express themselves," "are well prepared and know their subjects well," "spend time investigating" and "go to the bottom of things." A key element of their popularity, mentioned repeatedly, is that they let the public express itself, which is confirmed by the fact that, among all the favourite journalists mentioned, more than two thirds host participatory programmes which take live questions from listeners. ${ }^{45}$

Showing courage, offering a critical perspective, hosting contradictory debates, giving citizens the opportunity to speak out, and pursuing investigations: these characteristics have sometimes led these model journalists into trouble. In 2006, Domitille Kiramvu 
was imprisoned for several months after evoking an attempted coup against President Pierre Nkurunziza. The BBC programme in Kinyarwanda has already been suspended on several occasions, including once in 2009 after "Imvo n'Imvano" hosted Faustin Twagiramungu (1994-1995), the former president of Rwanda and a former candidate in the 2003 presidential elections, and broadcast his controversial claims.

During focus groups that were conducted within the surveyors' team, in order to discuss the results obtained in the field, as well as during the public presentation of the study's preliminary results, the question of the definition of "journalist" emerged repeatedly. Indeed, the surveyors noted that while some respondents clearly identified the most competent media professionals, many others, in particular in Rwanda and the DRC, confused "journalist" and "presenter." Several of those identified as favourites are in fact the presenters of variety programmes, or even pastors preaching on denominational radios. Moreover, some journalists identified as "favourites" were not seen by listeners as examples of professional integrity, but rather as the most provocative, known for spreading rumours, unverified "scoops," and the like. In the DRC, where listeners' choices seem more diversified, not only as regards the favourite journalists, but also the language in which they express themselves and the type of programme they host, the surveyors were surprised by the fact that a good command of language is a criterion often put forward: a "good" journalist is a journalist who speaks well (in French, Swahili or one of the other local languages), a point which proved quite controversial. It should be noted that while public radios were mentioned by listeners as radios that really were listened to (in particular the radio news), none of their staff is mentioned as a favourite journalist. ${ }^{46}$

From the analysis of the responses it emerges that what seems to establish, and give credibility to the work method of journalists, in the eyes of the listeners, is their ability to criticize and denounce, to contradict official information, to let people express themselves (through accounts within the radio news or through participatory programmes), far more than internal factors such as the verification and cross-checking of news in order to guarantee the reliability of the information.

What the study shows at bottom is that the listeners have their own definition of "journalism," which, according to Ewart et al., is a sign of "empowerment". ${ }^{47}$ The study certainly shows that perceptions 
have changed in 20 years, since the time when journalists acted as government spokesmen and where it would not have crossed the minds of listeners that journalists could use their citizen's right to access information. Journalists are now seen as the "voice of the voiceless," appreciated when they work "at the service of the people," daring to challenge the authorities and reveal their dysfunctions, and thus defending the population's interests with regard to the politicians and the official media discourses. This redefinition of the journalist's mission and role towards listeners thus reflects a repositioning of the citizen-listener who feels entitled to expect certain types of services from journalists or those who claim they are journalists. Perhaps this redefinition only partly covers that of the audiences of the Western media, but it highlights certain types of practices that might seem particularly important in the local context, which probably also encourages journalists to fulfil their function in a sense that makes them win the esteem of listeners ${ }^{48}$.

\section{CONCLUSION}

Our paper aimed to outline the way in which the definition of journalist has "shifted" over the past two decades in three countries of Central Africa, passing from a definition where the meaning of the profession was determined by an external actor (the State) to another where the media professionals themselves have tried to establish their own referents, while the change of practices in turn and the new post-conflict political environment generated new expectations and perceptions from the public. We have attempted to show that these changes do not constitute a simple cyclical evolution but represent a shift of journalistic paradigm. This change of paradigm is the consequence of several political, social and economic factors which have brought about a profound transformation of the principles, the values and professional practices. Following a period of 30 years when the public authorities imposed the only legitimate and politically acceptable definition of the profession, the liberalization of the sector enabled the development of a different approach to the sector. The political upheavals in the region and the involvement of certain media in the war propaganda of the 1990s then strongly disrupted the profession and marked the way in which it redefined itself, once peace had been established, through endogenous discourses (codes, charters) and exogenous discourses (legislation, training programmes). The turmoil of the last ten years 
has also transformed the way in which "good" journalists are perceived and evaluated today by the citizens, in this region where democracy is still largely under construction. The dynamics of reform as a whole led to a rapprochement with "international" professional referents, around notions of "opposition force," independence, search for the truth, and the journalist's responsibility towards citizens.

To a certain extent, the journalistic system has adapted rapidly to this new setting, redefining its way to operate; nevertheless a rupture appears in the confrontation of this new professional model with the economic parameters of the market. Is rigorous journalism (which promotes balance, responsibility, truth, the absence of bias or discriminatory discourse, as the journalists claim in their reference documents) viable on the Congolese, Burundian or Rwandan market? The constant threat of "coupage," "giti" or "per diem" shows the fragility of a professional practice which the frailty of the local financial resources cannot protect. As for the courageous, critical journalism, open to the voice of the citizens and which emerges from the public's new expectations, it faces reservations, even reprisals from the public authorities which have not rid themselves of their desire to control the news. This enmity increases the media's financial difficulties. Being the "voice of the voiceless" is a noble mission, but can one live of it and perform it scrupulously when the "voiceless" are also "penniless"?

These two challenges (bribed journalism and government control) can be looked at as new problems linked to the necessary adjusting of the actors to the new context, but also as the survival of some characteristics of the former paradigm: lip service journalism ("at the service of") and government control on legitimate speech.

In such a context, the overwhelming majority of media that pay attention to the "voiceless and penniless" have been able to do so thanks to the support of a number of donors and foreign partners who funded these model media that symbolize the renewal of the profession (RPA and Radio Isanganiro in Burundi, Radio Okapi or Radio Maendeleo in the DRC). But, although it has been considerable over the past decade, this support will not last forever. The journalists of Central Africa will then have to endeavour to continue to assert their attachment to this new profession they are in the process of building up, but whose consolidation has a price... A price that it is not certain that their audience, even if it wants to, will be able to afford. 


\section{NOTES}

1 Depending on the definition used, the African Great Lakes region comprises between 2 and 13 countries. The term is here used to refer to the three countries formerly under Belgian rule: the DRC, Burundi and Rwanda.

2 In the Congo there were newspapers that seemed to be privately owned but were in fact entirely financed by the State: they were called "journaux de la chaîne" (newspapers of the chain)

3 See André Badibanga, "La presse africaine et le culte de la personnalité," in Revue française d'études politiques africaines, vol.14, N0.159,1979, pp.40-57.

4 The previous piece of legislation in effect that regulated the freedom of the press in Burundi was the edict of March 51922 (approved by a decree of Aug. 6 1922) adopted by the Belgian colonial rulers to counter the propaganda liable to stir up the indigenous population against the colonial authority and the white colonizers. The law of 1976 was the first text to repeal this edict.

5 Abdou Latif Coulibaly et al. "Rapport du projet de réforme du cadre juridique de la presse et de la communication au Burundi," Sept. 2002, p. 18, qtd. in Maoundonodji Gilbert, Cadres juridiques et pratiques du pluralisme radiophonique, Paris, Karthala/Institut Panos Paris, p. 59.

6 Order-law 70/057 of 28 Oct. 1970 that repealed the decree-law of 9 Dec. 1960 on the regime of the national and foreign press.

7 Ministry of Information, "Bilan 1960-1970," Kinshasa, 1971, p. 105, cited by Tambwe Eddy, . Ecrit et pouvoir au Congo-Zaïre, 1885-1990: un siècle d'analyse bibliologique, Paris: L'Harmattan, 2001 , p.262.

8 Sakombi Inongo, Minister of Information, Mobilization and Propaganda, in Elima, 27 Jan. 1989, qtd. in Emmanuel Bebe Beshelemu, Presse écrite et expériences démocratiques au CongoZaïre, Paris, L'Harmattan, 2006, p. 110.

9 Sakombi Inongo, "Droits et responsabilités du journaliste," Conference held on April 1 1989, qtd. in Georges Tshionza Matata, Les médias au Zaïre. S'aligner ou se libérer, Paris, L'Harmattan, 2006, p. 41. 
10 Kayibanda Grégoire, "Lettre du Président de la République," in Dialogue no. 24, Jan. 1971, p. 5, qtd. in Annie Bart, La presse au Rwanda. Production, diffusion et lecture depuis le début du siècle, Postgraduate thesis, Jan. 1982, p. 162.

11 Juvenal Habyarimana, Message addressed to Dialogue no. 79, Mar.Apr. 1980, p. 2, qtd. in Annie Bart, op. cit. 1982, p.164.

12 The ISTI became the Ifasic (Institute for Information and Communication Sciences) in 1997.

13 Malembe Tamandiak, Director of ISTI, "L'information et la culture nationale: l'expérience zaïroise," in Institut culturel africain (ed.), La fonction culturelle de l'information en Afrique, Les nouvelles Editions africaines, Dakar-Lomé-Abidjan, 1985, p. 65 and 67.

14 Thierry Perret, Le Temps des journalistes. L'invention de la presse en Afrique francophone, Paris, Karthala, 2006.

15 From a regulatory perspective, this liberalization was ratified by a new press law adopted in 1992 in Burundi, in a speech by President Mobutu in 1990, and the adoption of a new press law in 1996 in Zaïre (DRC after 1997). Rwanda had to wait until 2002 for the first press law to be enacted.

16 Le Citoyen no. 12, June 1993, p. 7, qtd. in Eva Palmans, Médias et politique en situation de crise: le cas du Burundi, PhD thesis, University of Antwerp, 2008, p.251.

17 La Semaine no. 1, 29 May 1993, p. 1, qtd. in Eva Palmans, op. cit., p.252.

18 La Semaine no. 4, 9 July 1993, p. 7, qtd. in Eva Palmans, op. cit., p.252.

19 Among the more regular and better known ones are Le Potentiel, Le Phare, Umoja, Le Soft, La Prospérité and La Conscience. Elima, a former "journal de la chaîne," also joined the ranks of Mobutu opponents.

20 Gauthier de Villers, Zaïre 1990-1991. Faits et dits de la société d'après le regard de la presse, Les Cahiers du CEDAF-ASDOC, no. 12, 1992, p. 2.

21 Le Potentiel no. 53, Sept. 1990.

22 Emmanuel Bebe Beshelemu, Presse écrite et expériences démocratiques 
au Congo-Zaïre, Paris, L'Harmattan, 2006, p. 290.

23 See Frère Marie-Soleil, "After the Hate Media: Regulation in the DRC, Burundi and Rwanda," in Clobal Media and Communications, vol. 5, no. 3, Dec. 2009, Sage Publications, p. 327-352. For the case of Rwanda in particular, see Jean-Pierre Chrétien (ed.), Rwanda. Les médias du génocide, Paris, Karthala, 1995.

24 Jean-Marie Vianney Higiro, in Dialogue no. 175, Apr.-May 1994, p. 49-50.

25 Marie-Soleil Frère, Elections and the Media in Post-conflict Africa, London, Zed Books, 2011.

26 See Annie Laliberté, Autoritarisme et démocratie. Un journalisme de paix dans le Rwanda de l'après-génocide, PhD thesis in Anthropology, Université Laval, Quebec, 2009, and Thomas Hannitzsch, "Situating Peace Journalism in Journalism Studies: a critical appraisal," in Conflict and Communication online vol. 6, no. 2, 2007.

27 For instance, Radio Okapi was established jointly by the UN and the Swiss Foundation Hirondelle in the DRC, Studio ljambo was created by the American NCO Search for Common Ground in Burundi, while the soap opera Musekeweya was produced and broadcast by the Dutch NGO La Benevolencija in Rwanda.

28 A first code of ethics was adopted in 1993 by 230 journalists. It did not prevent the excesses of the Burundian press, called "hate press," between 1993 and 1996.

29 See the complete texts in Gérard Ntahe, Textes juridiques et déontologiques régissant la presse au Burundi, Paris, Institut Panos Paris, 2009; Jean Paul Kayihura, Code de déontologie et textes juridiques régissant les médias au Rwanda, Paris, Institut Panos Paris, 2009; Journalistes en danger / Institut Panos Paris (ed.) Comprendre les textes juridiques et déontologiques régissant la presse en RDC, Kinshasa, Institut Panos Paris, 2007.

30 RMEC never really operated properly. In 2013 a new self-regulatory body was established, called Rwanda Media Commission.

31 The two institutions merged in 2011.

32 A school briefly existed in Burundi, but closed its doors in 1991. 
33 The three main ones are Ifasic (Institute for Information and Communication Sciences), the Department of Social Communications of the FCK (Catholic Faculty of Kinshasa, later the Catholic University of the Congo or UCC), and the Department of Information and Communication Sciences of the University of Kinshasa. For more details see Marie-Soleil Frère, Le paysage médiatique congolais. Etat des lieux, enjeux et défis, Kinshasa, FEI, 2008.

34 On the teaching of professional ethics in particular, see Alfred Malanda Misanga, Les cadres éthiques et déontologiques dans les processus de formations journalistiques en RDC. Le cas de la Ville de Kinshasa, PhD thesis, Université catholique de Louvain, 2012.

35 Article 59 of the previous law, adopted in 2002, simply stipulated that: “The term 'journalist' refers to any person of Rwandan or foreign nationality in Rwanda who practises a profession of journalist on behalf of a newspaper."

36 The previous law in effect, the law of 2003, did not define the profession of journalist.

37 See MUNKENI-LAPESS Rigobert, Le coupage. Une pratique d'allocation des ressources dans contexte congolais des médias, Paris, L'Harmattan, 2009, and FAYE Mor, Presse privée écrite en Afrique francophone. Enjeux démocratiques, Paris, L'Harmattan, 2008.

38 Presidential and legislative elections were held in 2005 and 2010 in Burundi, in 2006 and 2011 in the DRC, and in 2003 (presidential and legislative), 2008 (legislative) and 2010 (presidential) in Rwanda.

39 United Nations Organization Stabilization Mission in the DRC: created in 1999 (under the name Monuc), its name and mandate were revised in 2010. It includes more than 22,000 troops, essentially positioned in the east of the country, to which one must add several thousand civilians.

40 The survey was conducted between May 2010 and Nov. 2012 in the context of a programme ("Broadcasting across the Great Lakes") carried out by the Institut Panos Paris (IPP). It aimed to define the habits and preferences of the listeners of five cities in which the IPP had developed a partnership with local radios. The methodology rested on the constitution of panels of listeners that were then formed to manage a questionnaire in their locality. The panellists met regularly (on five occasions) to discuss the results obtained during their interviews.

41 As of today, the 1,300 questionnaires have only been processed 
manually. Their digitization is ongoing. It is therefore as yet impossible to offer an analysis taking into account parameters such as age, gender and level of education of the respondent.

42 For a general overview of this survey's results, in particular regarding the consumed media and the motivation underlying preferences, see Marie-Soleil Frère, "Audience perception of radio stations and journalists in the Great Lakes region" (forthcoming).

43 A previous question in the survey concerned the respondents' favourite programme: "Kabizi" comes out far ahead in Bujumbura with $43 \%$ of the respondents citing it as their "favourite programme."

44 Audience surveys are rare in the three countries. Those that have been carried out never focused on the public's favourite media personalities. In Rwanda, a survey from 2009 (MHC/Incisive) asked about the most popular journalist. According to the results, Tidjara Kabendera came out ahead, mentioned by $19 \%$ of respondents. Neither the BBC nor its journalists are mentioned once in this survey, which seems to suggest that possible answers were limited to "national" media and journalists.

45 All programmes marked with a * are participatory call-in programmes.

46 Tidjana Kabendera works for Radio Rwanda, but she hosts both variety and radio-play programmes.

47 EWART Jacqui, MEADOWS Michael, FORDE Susan, FOXWELL Kerrie, "Though the ears of the audience : emerging definitions of news from community radio audiences", Paper presented to the Journalism Education Conference, Griffith University, 29 November - 2 December 2005, p.5

48 EWART Jacqui, MEADOWS Michael, FORDE Susan, FOXWELL Kerrie, op.cit., p.5

REFERENCES

BADIBANGA, A. La presse africaine et le culte de la personnalité. Revue française d'études politiques africaines, n. 156, Dec.1978, p. 40-57

BART, A. La presse au Rwanda. Production, diffusion et lecture depuis le début du siècle, 1982, 600 f. Thèse (3ème cycle). Université de Bordeaux 3, 1982.

BEBE BESHELEMU, E. Presse écrite et expériences démocratiques au 
Congo-Zaïre. Paris: L’Harmattan, 2006

CHARRON, J. ; DE BONVILLE. J. Le paradigme journalistique: usage et utilité du concept. Bucarest: CIFSIC, 2003.

CHRETIEN J-P. C. (ed.). Rwanda. Les médias du génocide. Paris: Karthala, 1995.

de VILLERS, G. Zaïre 1990-1991. Faits et dits de la société d'après le regard de la presse. Les Cahiers du CEDAF-ASDOC, n¹2, 1992.

EWART, J.; MEADOWS, M.; FORDE, S.; FOXWELL, K. Though the ears of the audience : emerging definitions of news from community radio audiences. Paper presented to the Journalism Education Conference, Griffith University, 29 November-2 December, 2005.

FRERE M-S. Le paysage médiatique congolais. Etat des lieux, enjeux et défis. Kinshasa: FEI, 2008.

FRERE M-S. After the Hate Media : Regulation in the DRC, Burundi and Rwanda. Global Media and Communications, vol.5, number 3, p. 327352, 2009a.

FRERE, M-S. Elections et médias en Afrique Centrale. Voie des urnes, voix de la paix ?. Paris: Karthala, 2009b.

FAYE, M. Presse privée écrite en Afrique francophone. Enjeux démocratiques. Paris: L'Harmattan, 2008.

HANNITZSCH, T. Situating Peace Journalism in Journalism Studies : a critical appraisal. Conflict and Communication online, vol.6, n², 2007.

HIGIRO, J-M V. Dialogue n¹ 75, avril-mai 1994, p. 49-50

INSTITUT PANOS PARIS (IPP). Cadres juridiques et pratiques du pluralisme radiophonique. Paris: Karthala/Institut Panos Paris, 2005.

JOURNALISTE EN DANGER (JED) / INSTITUT PANOS PARIS (IPP) (ED.). Comprendre les textes juridiques et déontologiques régissant la presse en RDC. Kinshasa: Institut Panos Paris, 2007

KAYIBANDA, G. Lettre du Président de la République. In Dialogue n²4, janvier 1971, p.5,

KAYIHURA, J. P. Code de déontologie et textes juridiques régissant les médias au Rwanda. Paris: Institut Panos Paris, 2009.

LALIBERTE, A. Autoritarisme et démocratie. Un journalisme de paix dans le Rwanda de l'après-génocide. Thèse (Doctorat en Anthropologie). Québec, Université Laval, 2009.

MALANDA MISANGA, A. Les cadres éthiques et déontologiques dans les processus de formations journalistiques en RDC. Le cas de la 
Ville de Kinshasa. Thèse (Doctorat). Louvain, Université catholique de Louvain, 2012

MALEMBE, T. L'information et la culture nationale : l'expérience zaïroise. In: INSTITUT CULTUREL AFRICAIN (ed.). La fonction culturelle de l'information en Afrique. Dakar-Lomé-Abidjan; Les nouvelles Edictions africaines, 1985.

MAOUNDONODJI, G. Cadres juridiques et pratiques du pluralisme radiophonique. Paris: Karthala/Institut Panos Paris, 2005.

MINISTERE DE L'INFORMATION. Bilan 1960-1970. Kinshasa, 1970.

MUNKENI-LAPESS, R. Le coupage. Une pratique d'allocation des ressources dans contexte congolais des médias. Paris: L'Harmattan, 2009.

NTAHE, G. Textes juridiques et déontologiques régissant la presse au Burundi. Paris: Institut Panos Paris, 2009.

PALMANS, E. Médias et politique en situation de crise: le cas du Burundi. Thesis (PhD). Antwerp (Belgium), University of Antwerp, 2008.

PERRET, T. Le Temps des journalistes. L'invention de la presse en Afrique francophone. Paris: Karthala, 2005.

TAMANDIAK, M. L'information et la culture nationale : l'expérience zaïroise. In: INSTITUT CULTUREL AFRICAIN (ed.). La fonction culturelle de I'information en Afrique. Dakar-Lomé-Abidjan, Les nouvelles Editions africaines, 1985, p. 65-67.

TSHIONZA MATATA, G. Les médias au Zaïre. S'aligner ou se libérer. Paris: L'Harmattan, 2006.

Marie-Soleil Frère is Senior Researcher at the National Fund for Scientific Research in Belgium and Professor at the Department of Information and Communication Sciences at the University of Brussels (ULB).

ARTICLE ORIGINALLY PUBLISHED ON JUNE 2014. 